\title{
Developing a Bilingual Fotonovela to Encourage Human Papillomavirus Preteen Immunization in California: A Case Study
}

\author{
Rebeca Montealegre Boyte ${ }^{1}$, Tammy Pilisuk ${ }^{1}$, Ana Consuelo Matiella ${ }^{2}$, and Everly Macario ${ }^{3}$ \\ ${ }^{1}$ California Department of Public Health \\ ${ }^{2}$ The Fotonovela Production Company \\ ${ }^{3}$ Public Health Communications Research Consultant
}

\begin{abstract}
Background. Cervical cancer affects Latinas disproportionately in the United States, especially in California. Fotonovelas are an entertaining educational medium within the Latino community. Purpose. The California Department of Public Health, Immunization Branch partnered with a fotonovela production company to develop a bilingual fotonovela to motivate Latina mothers of preteens to get their children vaccinated against human papillomavirus (HPV). This paper reviews the process of and lessons learned from creating and pilot testing the HPV fotonovela. Methods. We convened a 10-member advisory committee to guide the development of the fotonovela and field-tested the medium with three focus groups of Latina mothers of preteens $(n=22)$. The focus group participants completed a pre- and post-survey to assess knowledge gain after reading the fotonovela on their own. After participants completed the post-survey, the moderator facilitated a discussion. Results. The advisory committee identified barriers and myths around HPV vaccination and suggested culturally appropriate messaging for the fotonovela. The pre-/post-survey showed statistically significant knowledge gain on the HPV vaccine among focus group participants. Conclusion. We found that the fotonovela is a well-accepted educational vehicle for Latinas. An intervention/control study to test the effectiveness of a fotonovela and/or webnovela in bringing about measurable behavior change is needed.
\end{abstract}

(C) 2014 Californian Journal of Health Promotion. All rights reserved.

Keywords: Fotonovela, human papillomavirus (HPV), HPV vaccine, cervical cancer, Latino/Hispanic, preteen, Pap tests

\section{Introduction}

\section{Cervical Cancer and Latinas in the United States}

Cervical cancer is a disease that affects Latinas disproportionately (Reynolds, 2004). In 2012, there were an estimated 2,100 Latinas diagnosed with cervical cancer in the United States, with approximately 500 deaths. The cervical cancer incidence rate among Latinas residing in the United States, overall, is about 64\% higher than among non-Latina white women. A geographic analysis in the United States found that Latinas experience the highest cervical cancer incidence rates of any racial/ethnic group in every region (American Cancer Society, 2012) and have the second highest mortality rate from cervical cancer (National Latina Institute for Reproductive Health, 2007).

\section{Cervical Cancer and Latinas in California}

In 2008, the cervical cancer incidence rate per 100,000 women in California was 8.4 compared with 7.8 in the United States. The cervical cancer death rate per 100,000 women in California was 2.3-the same as for the United States (The Henry J. Kaiser Family Foundation, accessed 2014). Approximately 800,000 California women age 18 years and older, who need to be routinely screened, have never had a Pap test. In national statistics that consider geographic variations, ethnic disparities, and other patterns, California consistently has higher rates of cervical cancer than other regions. Cervical cancer is especially a problem for many women who have recently immigrated to California. Indeed, Latinas in California have the highest incidence of cervical cancer and the highest risk for developing cervical cancer than 
other racial/ethnic groups-more than twice as high as non-Latina white women. Latinas also suffer from one-third of invasive cervical cancers diagnosed each year in California (California Department of Health Care Services, accessed 2014).

\section{The Human Papillomavirus (HPV) and the HPV Vaccine}

The human papillomavirus (HPV) is sexually transmitted. Pre-invasive lesions can be cured $100 \%$ of the time (Reynolds, 2004). Localized early cervical cancer has a 92\% cure rate (Reynolds, 2004). Routine vaccination against HPV is recommended for 11-12 year-old girls and boys, ideally before they are exposed to the virus through sexual activity. The HPV vaccine protects against two HPV strains that cause 70\% of cervical cancers (CDC, 2007). The quadrivalent vaccine is also approved to protect against genital warts and vaginal, vulvar, and anal cancers (US Food and Drug Administration, 2009).

\section{Health Education Fotonovelas: An Overview}

One factor contributing to the high cervical cancer incidence among Latinas is a paucity of culturally competent information on HPV and Pap tests (Lechuga, et al., 2011; Scarinci, Garcés-Palacio, \& Partridge, 2007; Smith \& Gonzales, 2005; Reynolds, 2004), although more is becoming available. Recent Mexican immigrants to California were most likely to associate Pap tests with sexual promiscuity and the least likely to understand the link between HPV and cervical cancer (Baezconde-Garbanati, et al., 2013). Studies conducted recently indicate that Latina mothers of adolescents, who did not vaccinate their children, often cited lack of basic information about the vaccine or the infection as primary reasons for not vaccinating their children (Morales-Campos, et al., 2013; Godoy Verdugo, et al., 2013). Research has also demonstrated that it is not sufficient to simply provide health information in the language of the target population. Education materials must be adapted for different levels of overall literacy and for health literacy (Osborn, et al., 2011; Baker, et al., 1996). Fotonovelas are one type of tool that can be used for health education purposes (Valle, Yamada \& Matiella, 2006).
A fotonovela is a story that uses posed photographs (not illustrations), text bubbles with simple text, and a dramatic narrative with characters in common everyday situations (Cabassa, Contreras, Aragón, Molina, \& Baron, 2011; Flora, 1981). Fotonovela scholars date the origin of fotonovelas to post World War II, when photo-booklets were first produced in Italy as a by-product of the film industry. They began as pictorial summaries of Hollywood films and then evolved into their own unique medium. In 1979, Mexico published 70 million copies of fotonovelas and "historietas" (graphic novels with illustrations) per month (Herner, 1979). In the 1970s and 1980s, fotonovelas became a heavily utilized popular cultural communication and entertainment medium within the Latino community in the United States (Flora, 1981, 1982), as they served as a cultural bridge between an often impersonal, unfamiliar, and often alienating environment and the more familiar heritage of readers (Carrillo \& Lyson, 1983). Even today, fotonovelas are read and discussed among family members and neighbors (Hill \& Browner, 1982) and often loaned, rented, and resold (Cabassa, Contreras, Aragón, Molina, \& Baron, 2011; Flora, 1985; Hill \& Browner, 1982). This is especially germane among Latinos, as about 7 in 10 Latinos report obtaining health information through their social networks, including family, friends, churches, and community groups (Livingston, Minushkin, \& Cohn, 2008). (See Figure 1 for a sample cover and inside page of a 1980s Mexican fotonovela.)

\section{Figure 1}

Novelas de Amor Fotonovela, "El Cuarto Prohibido.” Novedades Editors. June 11, 1984.

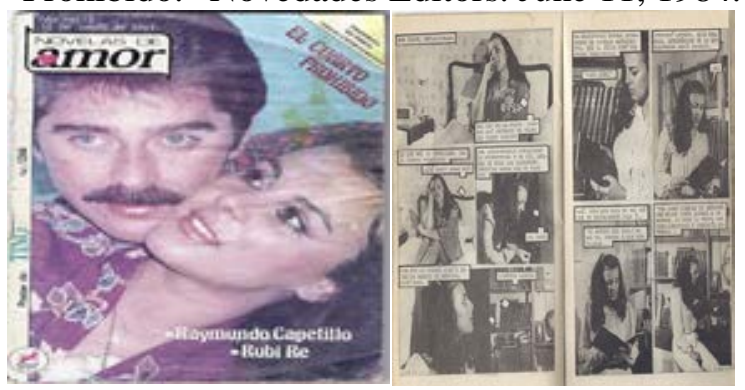




\section{Case Studies: Impact of Fotonovelas in Public Health}

Contemporary efforts to improve public health have utilized fotonovelas as an education tool. Health education fotonovelas follow "edutainment" principles, incorporating educational messages into popular entertainment narratives using consciousness raising and dramatic relief (Singhal \& Rogers, 1999). Although health education fotonovelas are built around an interesting and suspenseful storyline, their health-focused message predominates (Valle, Yamada \& Matiella, 2006). Furthermore, cognitive psychology research has shown that motivation to learn increases when education content relates to personal beliefs and experience through open-ended stories, sociodramas, and pictures depicting typical healthrelated situations (James et al., 2005).

In a recent focus group study, investigators examined reactions of Latinos, with limited English proficiency, to an adapted 30-page comic book-sized fotonovela on depression titled, "Secret Feelings” (Sentimientos Secretos), printed in English and Spanish with a fourth grade reading level. "Secret Feelings" featured authority figures (doctors) presenting the benefits of antidepressants and their appropriate use and side effects. Main characters modeled common concerns about these medications and how they overcame concerns by talking with doctors, pharmacists, and friends. One of those characters, however, had a negative experience because of delays in seeking care (Cabassa, Molina, \& Baron, 2012; Cabassa, Contreras, Aragón, Molina, \& Baron, 2011). Latinos in the study were randomly assigned to read the fotonovela or a low-literacy text pamphlet about depression. They completed surveys before reading each material, immediately after reading the material, and again one month later. Reading the fotonovela and text pamphlet resulted in significant improvements in depression knowledge and self-efficacy to identify depression, but the fotonovela produced significantly larger reductions in antidepressant stigma and mental health care stigma. The fotonovela was also more likely to be passed to family or friends after the study (Unger, Cabassa, Molina, Contreras, \& Baron, 2012).
Similarly, a dozen Latinas in a Milwaukee community participated in a pilot fotonovela intervention about healthy eating. Staff gave Latinas digital cameras with which to take photographs to be used as part of the fotonovela. Pre- and post-surveys showed that the fotonovela encouraged good health practices by increasing knowledge and cooperation among community members (Sberna Hinojosa et al., 2010). Additionally, an exploratory study suggested that an Alzheimer's fotonovela-based guided educational intervention, that considers the cultural context of illness, may provide a cost-effective tool for increasing the health literacy of hard-to-reach Latinos (Valle, Yamada \& Matiella, 2006). Most recently, an HPVthemed fotonovela was developed by the American Sexual Health Association (2014) produced in both traditional and webnovela formats, embedding messages about pap screening and the HPV vaccine in a culturallysensitive story.

\section{HPV Vaccination Rates are Low}

Despite the HPV vaccine's availability since 2006 and extensive advertising by one of the vaccine manufacturers, Merck \& Co., Inc., uptake of this vaccine is still low compared with other recommended immunizations for preteens 11-12 years. According to a CDC survey, 67.6\% of teen girls in California received $\geq 1$ dose of HPV vaccine, and only $45.8 \%$ had completed the 3-dose series in 2013. Additionally, only $16.6 \%$ of teen boys in California have completed the 3-dose series. If all opportunities for HPV vaccination had been utilized, coverage of adolescent females with $\geq 1$ dose of HPV vaccine in 2013 could have reached 91.3\% (CDC, 2014a, 2014b). While most parents report willingness to get the HPV vaccine for their adolescent daughters, some are unaware of, undecided about, or opposed to HPV vaccination, especially for younger daughters (i.e., 9-12 years) (Morales-Campos, et al., 2013; Kepka, et al., 2012; Freed, Clark, Buthart, Singer, \& Davis, 2010; Dempsey, Abraham, Dalton, \& Ruffin, 2009; Bernat, Harpin, Eisenberg, Bearinger, \& Resnick, 2009; Kahn et al., 2009; Brewer \& Fazekas, 2007; Zimet, Liddon, Rosenthal, Lazcano-Ponce, \& Allen, 2006). Researchers in Los Angeles conducted 
in-depth interviews with medical staff serving a predominantly Latino clientele about barriers and facilitators to providing the HPV vaccine. A dominant facilitator for Latinas in deciding to vaccinate their children was the receipt of information from peers (Javanbakht, et al., 2012). In another study, researchers interviewed 250 mothers about HPV vaccine acceptability and found that although $89 \%$ of mothers reacted positively to the possibility of vaccinating their daughters, they wanted more information about this vaccine's safety, effectiveness, and length of protection duration (Godoy Verdugo, Zonana Nacach, \& Anzaldo Campos, 2013).

\section{The Current Study}

By developing a bilingual (Spanish/English) fotonovela on HPV, the California Department of Public Health, Immunization Branch aimed to:

- Increase awareness about HPV and its strong association with cervical cancer.

- Increase awareness about Pap tests recommended for women over age 21 years.

- Increase awareness about the HPV vaccine, recommended for females and males 9-26 years.

- Motivate mothers of preteens (11-12 years) to get their children vaccinated against HPV.

This paper reviews the process of, and lessons learned from, creating and pilot testing the HPV fotonovela. Our case study explores how to address myths in the Latino culture that may hinder behavior change and how to best integrate Latino values and beliefs into a culturally-relevant story-telling format that may result in the adoption of healthy behaviors; in this case, vaccinating preteen children ages 1112 years against HPV. To our knowledge, there have not been any published case studies on fotonovelas that address these topics (e.g., HPV vaccine, HPV) among Latinos, and we are confident that this study advances our understanding of the importance of engaging the Latino community through non-traditional, rarely-used mediums in health education, such as fotonovelas.

\section{Methods}

\section{Study Design}

This study's methodology included both inperson focus groups and a confidential, selfadministered (pencil-and-paper) pre- and postsurvey. Focus group participants $(n=22)$ completed a pre-survey, then read the fotonovela and completed a post-survey. The pre- and postsurveys were the same instruments-three questions pertained to demographics, three were open-ended questions, and the remaining eight were multiple choice questions on HPV. Moderators facilitated a focus group discussion after all participants had completed both the preand post-surveys on their own to ensure that discussions would not influence individual survey responses.

\section{Participants}

All Latina mothers of preteens who showed were accepted as focus group participants. Participants gave a verbal agreement to participate in the focus group, which included the understanding that their comments would remain confidential and no names would be revealed in the summary report or a publication. To maintain confidentiality, we asked participants to use their first names only during the discussions.

Eligibility criteria included being a Latina woman age 18 years or older and having at least one male or female age 11 or 12 years in her care. Although we did not collect other socioeconomic information, we know informally from our recruitment efforts that many of the participants in Hayward and Richmond served as "promotoras" (lay Latina community members who receive training to provide basic health education in their local communities). The facilitator gave each participant a \$20 stipend at the conclusion of the discussion.

\section{Procedures}

The procedures for this study involved forming an advisory committee and partnering with The Fotonovela Production Company.

\section{Advisory Committee}


The California Department of Public Health, Immunization Branch convened a 10-member advisory committee to guide the development of the fotonovela. The committee was comprised of health educators, a public health consultant, two medical doctors, a public health nurse, and immunization coordinators housed at local health departments across California. Committee members were primarily foreign born, with representatives from Mexico, Central America, and South America. We recruited these public health professionals through our professional networks. They volunteered their time, as most specialized in preteen health and immunizations or had a keen interest in the process of developing a high quality HPV fotonovela. The team met bi-weekly via teleconference, or as needed. Frequent email communications also helped the project stay on track.

The primary function of the advisory committee was to ensure that 1) the fotonovela was written at the sixth grade reading level or below, 2) the storyline, messages, images, and actors were culturally appropriate, and 3) information was succinct yet conversational and engaging to naturally fit the informality of the medium.

Based on the advisory committee's input as well as literature research, we identified barriers, myths, and enablers regarding the HPV vaccine, and possible messages to include in the fotonovela to address each one (See Table 1).

\section{Partnering with The Fotonovela Production Company}

To develop the fotonovela, the California Department of Public Health partnered with The Fotonovela Production Company (TFPC). TFPC discussed barriers, motivators, and myths (See Table 1 and Table 2) with the advisory committee. Together, we explored questions including:

1. What are the objectives of the fotonovela?

2. What do we want the primary audience to do as a result of reading the fotonovela?

3. What are the values consistent with Latino families that we want to promote?
4. Where do we intend to distribute the fotonovela?

5. Who should be the main characters (ages and other characteristics)?

6. Who are the gatekeepers that need consideration?

7. What will be the reading level of the fotonovela?

8. What is complex or challenging about the information we are trying to convey?

\section{Table 1}

Barriers to Getting the HPV Vaccine and Possible Solutions/Messages

Barriers to Possible solutions/messages
getting the HPV
vaccine

\begin{tabular}{|c|c|}
\hline $\begin{array}{l}\text { Getting the HPV } \\
\text { vaccine is } \\
\text { condoning sex. }\end{array}$ & $\begin{array}{l}\text { - Putting a helmet on a child is not } \\
\text { permission for reckless riding. It } \\
\text { is a preventative measure, just } \\
\text { like the HPV vaccine. } \\
\text { - The HPV vaccine protects and } \\
\text { prevents disease. } \\
\text { - Kids' values do not change after } \\
\text { an immunization. }\end{array}$ \\
\hline $\begin{array}{l}\text { Having an } \\
\text { STD/sex } \\
\text { conversation. }\end{array}$ & $\begin{array}{l}\text { - De-emphasize genital warts as } \\
\text { much as possible (but must still } \\
\text { be included). } \\
\text { - Focus on cancer prevention. } \\
\text { - Highlight the fact that kids are } \\
\text { receptive to their parents and } \\
\text { want to hear what parents have to } \\
\text { say about sex and family values. }\end{array}$ \\
\hline $\begin{array}{l}\text { Concerns about } \\
\text { side effects. }\end{array}$ & $\begin{array}{l}\text { - Mention that the HPV vaccine } \\
\text { causes discomfort, not pain. } \\
\text { - Millions of women around the } \\
\text { world have been vaccinated } \\
\text { against HPV safely. }\end{array}$ \\
\hline $\begin{array}{l}\text { Confusion about } \\
\text { vaccines: } \\
\text { 3-shot series, } \\
2 \text { different } \\
\text { vaccines. }\end{array}$ & $\begin{array}{l}\text { - Include information about the } \\
\text { HPV vaccine dosage. } \\
\text { - Include information about the } \\
\text { difference between } 2 \text { different } \\
\text { HPV vaccines. }\end{array}$ \\
\hline
\end{tabular}

After answering these questions, TFPC was ready to begin brainstorming possible story synopses. TFPC presented two story summaries, and the advisory committee selected one that the team felt would be best suited to convey the intended health messages. TFPC further developed the story, and the advisory committee provided feedback on the first draft to ensure all 
objectives were met. We also turned to available research to guide our decision of photos versus drawings. Newly-immigrated older Latinas (over 30 years) are more likely to be diagnosed with cervical cancer and also prefer photographs over cartoon images (Matiella, Valle, Archer, \& Matiella-Murphy, 2010).

\section{Table 2}

Myths about the HPV Vaccine and Possible Solutions/Messages

\begin{tabular}{|c|c|}
\hline HPV vaccine myths & $\begin{array}{l}\text { Possible } \\
\text { solutions/messages }\end{array}$ \\
\hline $\begin{array}{l}\text { The HPV vaccine is only } \\
\text { for girls }\end{array}$ & $\begin{array}{l}\text { - Emphasize that the } \\
\text { HPV vaccine is for girls } \\
\text { AND boys, ages 9-26 } \\
\text { years. } \\
\text { - Include a preteen boy in } \\
\text { the fotonovela who also } \\
\text { gets vaccinated against } \\
\text { HPV. }\end{array}$ \\
\hline $\begin{array}{l}\text { Preteens are too young to } \\
\text { get the HPV vaccine. } \\
\text { The HPV vaccine is only } \\
\text { for older, sexually active } \\
\text { women and men. }\end{array}$ & $\begin{array}{l}\text { - The body’s immune } \\
\text { system responds best to } \\
\text { the vaccine at } 11-12 \\
\text { years. } \\
\text { - The HPV vaccine works } \\
\text { best well before having } \\
\text { sex. It is important that } \\
\text { preteens get it now to } \\
\text { protect them in } \\
\text { adulthood. }\end{array}$ \\
\hline $\begin{array}{l}\text { Pap tests are no longer } \\
\text { needed after getting the } \\
\text { HPV vaccine. }\end{array}$ & $\begin{array}{l}\text { While the HPV vaccine } \\
\text { is highly effective at } \\
\text { preventing cervical } \\
\text { cancer, it does not } \\
\text { prevent against all types } \\
\text { of HPV that can cause } \\
\text { cervical cancer. Pap } \\
\text { tests are still needed } \\
\text { starting at age } 21 \text { years. }\end{array}$ \\
\hline $\begin{array}{l}\text { The HPV vaccine is not } \\
\text { needed if one is already } \\
\text { sexually active. }\end{array}$ & $\begin{array}{l}\text { - It is best to give the } \\
\text { HPV vaccine before the } \\
\text { onset of sexual activity. } \\
\text { - Few sexually active } \\
\text { young women and men } \\
\text { are infected with all } \\
\text { HPV types covered by } \\
\text { the HPV vaccine, so } \\
\text { they would still get } \\
\text { protection from those } \\
\text { types that they have not } \\
\text { been exposed to. }\end{array}$ \\
\hline
\end{tabular}

The storyline that the team agreed would be effective is the following: Luci visits her neighbor, Sarita, and learns that Sarita's 35 year-old sister, Lourdes, mother of two, has cervical cancer. Sarita tells Luci this could have been prevented, but Lourdes never had Pap tests. Sarita explains that cervical cancer is caused by HPV-and that Luci should vaccinate her preteen son and daughter to protect them. To Luci's surprise, she learns that there is an $H P V$ vaccine for girls and boys! In fact, there are two HPV vaccines; one protects against several cancers (including cervical cancer) and genital warts, and the other protects against cervical cancer. Luci's husband objects, thinking his children are "too innocent" for the vaccine. The grandfather intervenes, convincing Luci's husband that getting the vaccine does not condone having sex. Luci has her kids vaccinated against HPV, and with the doctor's urging, gets a Pap test herself. The prognosis for Lourdes does not look good.

Once the story was close to final, TFPC contracted with a local theater company to identify actors for the fotonovela. The advisory committee sifted through several head shots to select the best actors for the job. Soon after, the photo-shoot took place and TFPC provided a near final version of the fotonovela.

Lastly, the advisory committee reviewed the fotonovela once again to assure that the script and photographs were naturally fitting. At times, the text seemed too long, and the team worked on shortening the language to ensure an appropriate balance between the photographs and the text in each scene. Once complete, the fotonovela was ready for field-testing.

\section{Focus Groups}

To explore perceptions and opinions of the messages included in fotonovela, we field-tested the first galley proof of the fotonovela. The California Department of Public Health, Immunization Branch and TFPC conducted three focus groups - one each in Hayward, Santa Cruz, and Richmond, California-during January 2011 with a combined total of 22 Latina mothers of preteen (11-12 years) boys and/or girls. We recruited participants through local 
contacts in Hayward at the Tiburcio Vasquez Health Center, at Richmond's Latina Center, and from a personal contact of the moderator in Santa Cruz.

A trained and experienced bilingual/bicultural moderator facilitated all focus groups, each approximately 90 minutes in length, using a structured moderator's guide. In Hayward and Santa Cruz, the moderator facilitated two groups in Spanish. The moderator facilitated the Richmond group in both Spanish and English, allowing participants to speak both languages, switching back and forth to maintain a level of comfort for all while primarily reviewing the English version of the fotonovela. We held focus groups in community settings in Santa Cruz and Richmond. In Hayward, we conducted the focus group in a conference room belonging to the clinic. A bilingual/bicultural note-taker took notes during all discussions.

\section{Measures: Pre- and Post-Survey}

All focus group participants completed a fourteen question pre-survey and post-survey by hand to measure knowledge gain before and after reading the fotonovela on their own. The survey was available in English or Spanish, according to the preference of the participant. The participants took approximately 8-10 minutes to read the fotonovela. Most survey items included closed-ended response categories. Respondents could voice their responses in their own words through three open-ended questions. The survey took approximately 7-10 minutes to complete.

\section{Analyses}

The project team compiled the pre- and postsurveys from participants in each focus group and scored the individual survey items for aggregate knowledge gain. We employed a McNemar's test to assess whether knowledge gain was statistically significant on eight different measures and a samples t-test to determine if the overall knowledge gain was also statistically significant. Moreover, the project team reviewed all the notes on the discussions and extracted themes recurring across the three focus groups. Project team members discussed the findings and arrived at consensus on conclusions.

\section{Results}

\section{Quantitative Results}

We conducted 3 focus groups with a total of 22 California-based Latina mothers of preteen (1112 years) boys and/or girls. Participants ranged in age from 30 to 66 years $(M=43.1$ years, $S D=$ 9.7). Participants self-identified as either Latina or Mexican, except for two women who selfidentified as Peruvian. Most participants preferred to speak Spanish and some were bilingual. Focus group participants completed a pencil-and-paper pre- and post- survey to assess knowledge gain after reading the fotonovela on their own. There was notable knowledge gain among focus group participants in five out of eight measures. Taken together, we identified an increase of $9 \%$ on "How does one get HPV?," $72.8 \%$ on "What does the HPV vaccine prevent?," $54.5 \%$ on "Who can get the HPV vaccine?," $68.2 \%$ on "How many HPV shots are needed?," and $31.9 \%$ on "Do women who receive HPV vaccine still need regular Pap tests?" See Table 3. A McNemar's test demonstrated that participants experienced statistically significant knowledge gain for each of these five questions after reading the fotonovela. Additionally, a paired samples t-test showed that total knowledge gain for all eight measures was also statistically significant $(\mathrm{p}<$ 0.0001).

\section{Qualitative Results}

All focus group participants liked the Más vale prevenir que lamentar (An ounce of prevention) fotonovela format for learning about a health issue, particularly because the story is related by "comadres" (close friends) and an elder family member, the grandfather, who confers moral authority. All participants understood the main messages of the fotonovela to be the importance of getting preteens vaccinated against HPV, getting a Pap test, and preventing cervical cancer. All agreed it was easy to locate where, inside the fotonovela, to look up more information. 
One group made a recommendation about wording, specifying that "genital warts" be explicitly spelled out as "verrugas en el pene $y$ en la vagina" (warts on the penis and the vagina). Participants were less familiar with the word "genital," and some thought it might apply only to females. To ensure that readers would not confuse $H P V$ with HIV (especially because the Spanish acronyms are "VPH" and "VIH," respectively), participants recommended spelling out "human papillomavirus" in both Spanish and English.

Table 3

Difference in Participants ( $\mathrm{N}=22)$ Reporting Correct Responses in Pre-and Post-tests

\begin{tabular}{|c|c|c|c|}
\hline Question & $\begin{array}{c}\text { Pre-test } \\
\text { Number of } \\
\text { Correct } \\
\text { Responses }\end{array}$ & $\begin{array}{c}\text { Post-test } \\
\text { Number of } \\
\text { Correct } \\
\text { Responses }\end{array}$ & p-value \\
\hline $\begin{array}{c}\text { How does one } \\
\text { get HPV? }\end{array}$ & $\begin{array}{c}10 \\
(45.5 \%)\end{array}$ & $\begin{array}{c}12 \\
(54.5 \%)\end{array}$ & $<0.001^{*}$ \\
\hline $\begin{array}{c}\text { What does the } \\
\text { HPV vaccine } \\
\text { prevent? }\end{array}$ & $\begin{array}{c}1 \\
(4.5 \%)\end{array}$ & $\begin{array}{c}17 \\
(77.3 \%)\end{array}$ & $<0.001^{*}$ \\
\hline $\begin{array}{c}\text { Can the HPV } \\
\text { vaccine cure } \\
\text { HPV? }\end{array}$ & $\begin{array}{c}13 \\
(59.1 \%)\end{array}$ & $\begin{array}{c}17 \\
(77.3 \%)\end{array}$ & 0.10 \\
\hline $\begin{array}{l}\text { Who can get } \\
\text { the HPV } \\
\text { vaccine? }\end{array}$ & $\begin{array}{c}10 \\
(45.5 \%)\end{array}$ & $\begin{array}{l}22 \\
(100 \%)\end{array}$ & $0.001 *$ \\
\hline $\begin{array}{l}\text { What is the } \\
\text { best time to } \\
\text { receive the } \\
\text { HPV vaccine? }\end{array}$ & $\begin{array}{c}18 \\
(81.8 \%)\end{array}$ & $\begin{array}{c}20 \\
(90.9 \%)\end{array}$ & 0.41 \\
\hline $\begin{array}{c}\text { How many } \\
\text { HPV shots are } \\
\text { needed? }\end{array}$ & $\begin{array}{c}4 \\
(18.2 \%)\end{array}$ & $\begin{array}{c}19 \\
(86.4 \%)\end{array}$ & $<0.001^{*}$ \\
\hline $\begin{array}{l}\text { Still need } \\
\text { regular Pap- } \\
\text { Tests if woman } \\
\text { is vaccinated? }\end{array}$ & $\begin{array}{c}14 \\
(63.6 \%)\end{array}$ & $\begin{array}{c}21 \\
(95.5 \%)\end{array}$ & $0.008 *$ \\
\hline $\begin{array}{c}\text { Should } \\
\text { sexually-active } \\
\text { people get } \\
\text { vaccinated? }\end{array}$ & $\begin{array}{c}15 \\
(68.2 \%)\end{array}$ & $\begin{array}{c}20 \\
(90.9 \%)\end{array}$ & 0.06 \\
\hline
\end{tabular}

Participants in one focus group emphasized the importance of reassuring parents about two sensitive issues: teen sexuality and vaccine safety-topics that extended beyond the existing text in the fotonovela story. These participants stated that there are strongly-held beliefs in their community that vaccination at a young age may encourage sexual promiscuity and that the fotonovela should address this more directly.

- "I would have liked you to address that myth, the myth that when you vaccinate your child against HPV that you are encouraging your child to have sex."

- "Yes, it does come out in the fotonovela, but we are still left with that question: 'Are we encouraging our children to have sex?'”

Other participants, who also worked as promotoras, felt strongly that addressing this myth was critically important. Stemming from another charged discussion, participants in the both Hayward and Santa Cruz expressed concerns about possible vaccine side effects.

- "The doctor said this [HPV] vaccine was optional."

- "This is a new vaccine; I don't want my child to be a guinea pig."

Participants felt that side effects and safety concerns were not adequately addressed in the story and therefore requested including a more definitive statement on vaccine safety in the fotonovela.

During 2011-2012, the California Department of Public Health, Immunization Branch distributed over 15,000 copies of the Más vale prevenir que lamentar (An ounce of prevention) fotonovela (See Figure 2). We temporarily stopped distribution in 2013 to make minor content updates and reprint. We received anecdotal feedback from two California Latino-oriented clinics that distributed the fotonovela to Latino parents of adolescent patients, primarily mothers, at their clinic. One clinic raised their HPV vaccine initiation rates from $50 \%$ to $80 \%$ after they invited Latinas to read the fotonovela at the clinic's waiting room. Another clinic also 
reported increasing HPV 3-shot series completion rates from $60 \%$ to $80 \%$ after introducing the fotonovela in their exam rooms.

Figure 2

Final English-language Fotonovela Cover (Spanish and English versions are available back to back in the same fotonovela)

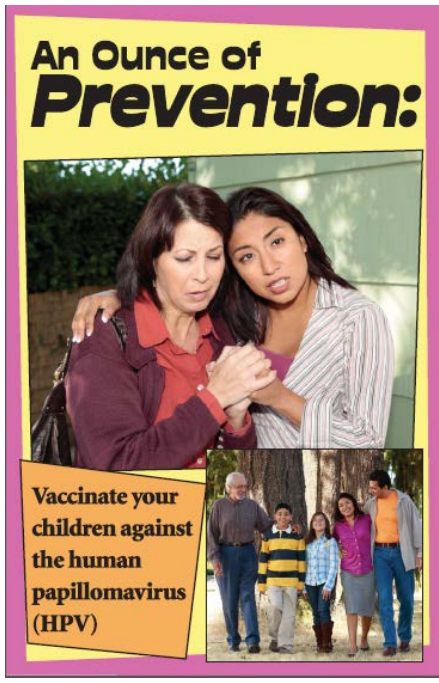

\section{Discussion}

This case study examined the development and lessons learned from creating and pilot testing a fotonovela aimed at Latina mothers of preteens ages 11 and 12 years. The fotonovela increased initiation and completion rates of the human papilloma virus (HPV) vaccine series in two clinics using the educational medium, in addition to improving knowledge of the HPV vaccine among focus group participants. The process and findings described throughout may help inform future health initiatives intended for Latinos in California.

Field-testing an initial version of the Más vale prevenir que lamentar (An ounce of prevention) fotonovela helped fine-tune the fotonovela to ensure messages are clear, concise, and culturally competent. We spelled out "human papillomavirus" on the cover page to avoid any confusion between HPV and HIV, and we repeated the use of the full word inside the fotonovela at first mention of "HPV" to enhance clarity. We removed the term "genital warts," replacing it with the less clinical phrase, "warts on the penis and on the vagina," in both English and Spanish.

To address content that went beyond the story dialogue, we used the fotonovela's didactic section, presented as a Q\&A from the pediatrician character. Examples: "Why is the HPV vaccine given at such an early age?," "How can I talk to my children about the HPV vaccine?," and "What are HPV vaccine's side effects?”

In June 2013, the California Department of Public Health informally concept-tested the fotonovela with 24 parents of preteens from diverse racial/ethnic origins during individual indepth interviews. We wanted to explore whether the fotonovela format would appeal to parents outside of the Latino culture. We handed nonLatino parents a copy of the fotonovela to look at along with the instruction, "Imagine the characters looked more like you and your family." Non-Latino parents responded unfavorably to the fotonovela, often confusing it with a comic intended for children or teens. In contrast, Latino parents continued to respond favorably. This affirms the importance of testing all health education materials with every intended target audience.

A digital version of the final fotonovela, a "webnovela," is also available as an adjunct product in Spanish at VacunasYMiSalud.org. The webnovela is a less-explored vehicle for content, as it requires additional resources to hire talent to read the audio scripts, edit and create the completed file, and a web platform to host the final product. In our case, we also lacked data to know who viewed it, under what circumstances, and what impression the webnovela made on those who viewed it. Future research could explore how the webnovela format and content could be useful to specific target audiences in clinics, community settings, and homes as well as on mobile devices. As web technologies continue to become more ubiquitous, this may be a new frontier for an old medium.

Future research also needs to include the design of an intervention/control study to test the 
effectiveness of a fotonovela and/or webnovela in bringing about measurable behavior change or a shift in participants' intention to immunize their children with the HPV vaccine. Future investigations could additionally benefit from studying whether fotonovelas are more effective with one-on-one interaction or sufficient on their own at motivating behavior change. Such investigations would add to the evidence-base knowledge in this field.

\section{Limitations}

As our focus group study was small in scale and exploratory in nature, the findings are limited and preliminary in nature. We did not recruit focus group participants randomly, and there was potential for participant self-selection and social desirability biases. To our knowledge, however, there has not been any previous published research on fotonovelas, as defined in this paper, covering the topic of HPV, the HPV vaccine, Pap tests, and cervical cancer targeting a United States Latina audience. We thus believe that the lessons learned from the process of developing the fotonovela described in this paper can be helpful to health education product developers interested in reaching Latino populations.

\section{Conclusion}

Based on our experience, we believe the fotonovela is a useful and well-accepted educational vehicle for Latinas. The pre- and post-surveys demonstrated statistically significant knowledge gain on the human papillomavirus (HPV) vaccine among focus group participants. Additionally, one community-based clinic reported a 30\% increase in HPV vaccine initiation rates and another reported a $20 \%$ increase in the HPV 3-shot series completion after introducing the fotonovela to parents of adolescents. As such, the fotonovela format holds promise in teaching health information on a variety of topics such as other immunization topics, cancer prevention, diabetes, nutrition, and healthy eating to this population. Further research is needed to evaluate the impact of fotonovelas in motivating behavior change.

\section{References}

American Cancer Society. Cancer Facts and Figures for Hispanics/Latinos 2012-2014. Atlanta: American Cancer Society, 2012. Available at: http://www.cancer.org/acs/groups/content/@epidemiologysurveilance/documents/document/acspc034778.pdf. Accessed March 13, 2014.

American Sexual Health Association (2014). Protecting Ourselves and Our Families from Cervical Cancer/Protegernos a Nosotras Mismas y a Nuestras Familias del Cáncer Cervical. [Fotonovela]. Available at: http://www.ashapublications.org/protegernos-a-nosotras-mismas-y-a-nuestras-familiasdel-cancer-cervical/

Baezconde-Garbanati, L., Murphy, S. T., Moran, M. B., \& Cortessis, V.K. (2013). Reducing the excess burden of cervical cancer among Latinas: Translating science into health promotion initiatives. California Journal of Health Promotion, 11(1), 45-57.

Baker, D., Parker R., Williams, M., Pitkin, K., Prikh, N., Coates, W., et al. (1996). The health care of patients with low literacy. Archives of Family Medicine, 5, 329-334.

Bernat, D. H., Harpin, S. B., Eisenberg, M. E., Bearinger, L. H., \& Resnick, M. D. (2009). Parental support for the human papillomavirus vaccine. Journal of Adolescent Health, 45, 525-527.

Brewer, N. T., \& Fazekas, K. I. (2007). Predictors of HPV vaccine acceptability: A theory-informed systematic review. Preventive Medicine, 45, 107-114.

Cabassa, L. J., Contreras, S., Aragón, R., Molina, G. B., \& Baron, M. (2011). Focus group evaluation of "Secret Feelings:" A depression fotonovela for Latinos with limited English proficiency. Health Promotion Practice, 12, 840-847.

Cabassa, L. J., Molina, G. B., \& Baron, M. (2012). Depression fotonovela: development of a depression literacy tool for Latinos with limited English proficiency. Health Promotion Practice, 13, 747-754.

Cabrera, D. M., Morisky, D.E., \& Chin, S. (2002). Development of a tuberculosis education booklet for Latino immigrant patients. Patient Education and Counseling, 46, 117-124. 
California Department of Health Services. Cancer Detection Programs: Every Woman Counts. Cervical Cancer Fact Sheet. Available at: http://www.cdph.ca.gov/HealthInfo/discond/Documents/cervicalcancer.pdf. Accessed March 13, 2014.

Carrillo, L., \& Lyson, T., A. (1983). The fotonovela as a cultural bridge for Hispanic women in the United States. Journal of Popular Culture, 17, 59-64.

Centers for Disease Control and Prevention. (CDC). (2014, July 25). National, Regional, State, and

Selected Local Area Vaccination Coverage Among Adolescents Aged 13-17 Years - United States, 2013. MMWR. Morbidity and Mortality Weekly Reports. Retrieved from:

http://www.cdc.gov/mmwr/preview/mmwrhtml/mm6329a4.htmCenters for Disease Control and Prevention. (CDC). (2014, July 25). Human Papillomavirus Vaccination

Coverage Among Adolescents, 2007-2013, and Postlicensure Vaccine Safety Monitoring, 20062014 - United States. MMWR. Morbidity and Mortality Weekly Reports. Retrieved from: http://www.cdc.gov/mmwr/preview/mmwrhtml/mm6329a3.htm

Centers for Disease Control and Prevention (CDC). (2007, March 23). Quadrivalent human papillomavirus vaccine: Recommendations of the Advisory Committee on Immunization practices (ACIP). MMWR. Morbidity and Mortality Weekly Report. Retrieved from: http://www.cdc.gov/mmwr/preview/mmwrhtml/rr5602a1.htm

Dempsey, A. F., Abraham, L. M., Dalton, V., \& Ruffin, M. (2009). Understanding the reasons why mothers do or do not have their adolescent daughters vaccinated against human papillomavirus. Annals of Epidemiology, 19, 531-538.

Flora, C. (1981). Fotonovelas: Message creation and reception. Journal for Popular Culture, 14, 524-534. Flora, C. (1982). The fotonovela in America. Studies in Latin American Popular Culture, 6, 15-26.

Flora, C. (1985). Maids in the Mexican photonovela. Studies in Latin American Popular Culture, 4, 8494.

Freed, G. L., Clark S. J., Butchart, A. T., Singer D. C., \& Davis, M. M. (2010). Parental vaccine safety concerns in 2009. Pediatrics, 125, 654-659.

Godoy Verdugo, M. K., Zonana Nacach, A., \& Anzaldo Campos, M. C. (2013). Aceptación de la vacuna contra el virus del papiloma humano por parte de madres de hijas entre 9 y 13 años de edad. [Acceptance of the vaccine against human papilloma virus from mothers to daughters aged 9 to 13 years old.] Ginecología y Obstetricia de México, 81, 645-651.

The Henry J. Kaiser Family Foundation. (2014). State Health Facts Women’s Health Indicators. Available at: http://www.statehealthfacts.org/profileind.jsp?cat=10\&sub=112\&rgn=6. Accessed March 13, 2014.

Herner, Irene. Mitos y Monitos: Historietas y Fotonovelas en México. Mexico, D.F.: Universidad Autónoma de México, 1979.

Hill, J., \& Browner, C. (1982). Gender ambiguity and class stereotyping in the Mexican fotonovela. Studies in Latin American Popular Culture, 1, 48-64.

James, S., Reddy, P. S., Ruiter, R. A. C., Taylor, M., Jinabhai, C. C., Van Empelen P., \& Van Den Borne, B. (2005). The effects of a systematically developed photo-novella on knowledge, attitudes, communication and behavioral intentions with respect to sexually transmitted infections among secondary school learners in South Africa. Health Promotion International, 20, 157-165.

Javanbakht, M., Stahlman, S., Walker, S., Gottlieb, S., Markowitz, L., Liddon, N., Plant, A. \& Guerry, S. (2012). Provider perceptions of barriers and facilitators of HPV vaccination in a high-risk community. Vaccine, 30, 4511-4516.

Kahn, J. A., Ding, L., Huang, B., Zimet, G. D., Rosenthal, S. L., \& Frazier, A. L. (2009). Mothers' intention for their daughters and themselves to receive the human papillomavirus vaccine: A national study of nurses. Pediatrics, 123, 1439-1445.

Kepka, D. L., Ulrich, A. K., \& Coronado, G.D. (2012). Low knowledge of the three-dose HPV vaccine series among mothers of rural Hispanic adolescents. Journal of Health Care for the Poor and Underserved, 2, 626-35. 
Lechuga, J., Swain, G. R., \& Weinhardt, L. S. (2011). Impact of framing on intentions to vaccinate daughters against HPV: A cross-cultural perspective. Annals of Behavioral Medicine, 2, 221-226.

Livingston, G., Minushkin, S., \& Cohn, D. (2008). Access, Information and Knowledge. Hispanics and Health Care in the United States. Pew Research Hispanic Center. Retrieved from: http://www.pewhispanic.org/2008/08/13/hispanics-and-health-care-in-the-united-states-accessinformation-and-knowledge/

Matiella, A. C., Valle, R., Archer, G., \& Matiella-Murphy, L. ¡A Su Salud! Fotonovela Strips (Fotocintas) in Spanish Language Newspapers. Report on Phase I of the NIH/NCI/SBIR Funded Research, Grant \# 1 R43 CA135999-01A1 6 ZRG1 RPHB-C (10). February 4, 2010.

Morales-Campos, D. Y., Markham, C. M., Peskham, M. F., \& Fernadez, M. E. (2013). Hispanic mothers' and high school girls' perceptions of cervical cancer, and the human papilloma virus vaccine. Journal of Adolescent Health, 52, S69-75.National Latina Institute for Reproductive Health. (2007, October). Latinas and Cervical Cancer Fact Sheet. Retrieved from:

http://latinainstitute.org/sites/default/files/CervicalCancerFactsheet-Oct07.pdf

Osborn, C. Y., Paasche-Orlow, M. K., Bailey, S. C., \& Wolf, M. S. (2011). The mechanisms linking health literacy to behavior and health status. American Journal of Health Behavior, 1, 118-128.

Reynolds, D. (2004). Cervical cancer in Hispanic/Latino women. Clinical Journal of Oncology Medicine, $8,146-150$.

Sberna Hinojosa, M. S., Hinojosa, R., Nelson D. A., Delgado, A., Witzack, B., Gonzalez, M., et al. (2010). Salud de la Mujer: using fotonovelas to increase heath literacy among Latinas. Progress in Community Health Partnerships: Research, Education, and Action, 4, 25-30.

Scarinci, I. C., Garcés-Palacio, I. C., \& Partridge E. E. (2007). An examination of acceptability of HPV vaccination among African American women and Latina Immigrants. Journal of Women's Health, $16,1224-1233$.

Singhal, A., \& Rogers, E. (1999). Entertainment-education: A communication strategy for social change. Mahwah, NJ: Lawrence Erlbaum.

Smith, S. A., \& Gonzales, V. (2005). Developing culturally and linguistically appropriate health education materials. Studies in Communication Sciences, 2, 111-128.

Unger, J. B., Cabassa, L. J., Molina, G. B., Contreras, S., \& Baron, M. (2012). Evaluation of a fotonovela to increase depression knowledge and reduce stigma among Hispanic adults. Journal of Immigrant and Minority Health. [Epub ahead of print]

U.S. Food and Drug Administration. (2009). FDA licenses quadrivalent human papillomavirus (types 6, $11,16,18)$ recombinant vaccine (Gardasil) for the prevention of cervical cancer and other diseases in females caused by human papillomavirus. Available at:

http://www.fda.gov/aboutfda/centersoffices/officeofmedicalproductsandtobacco/cder/ucm095647.htm . Accessed March 13, 2014.

Valle, R., Yamada, A. M., \& Matiella, A. C. (2006). Heath literacy tool for educating Latino older adults about dementia. Clinical Gerontologist, 30, 71-88.

Zimet, G. D., Liddon, N., Rosenthal, S. L., Lazcano-Ponce, E., \& Allen, B. (2006). Chapter 24: Psychosocial aspects of vaccine acceptability. Vaccine, 24, S201-S209.

Author Information

*Rebeca Montealegre Boyte, M.A.S., CLEC

Health Educator Supervisor

Information \& Education Section

Immunization Branch

Division of Communicable Disease Control

Center for Infectious Diseases

California Department of Public Health

850 Marina Bay Parkway, Building P, 2nd Floor 
Richmond, CA 94804

510-620-3762 phone

Rebeca.Boyte@cdph.ca.gov

Tammy Pilisuk, M.P.H.

Health Educator

Information \& Education Section

Immunization Branch

Division of Communicable Disease Control

Center for Infectious Diseases

California Department of Public Health

850 Marina Bay Parkway, Bldg. P, 2nd Floor

Richmond, CA 94804

510-620-3753 phone

Tammy.Pilisuk@cdph.ca.gov

Ana Consuelo Matiella, M.A.

President

The Fotonovela Production Company

33 Camarada Road

Santa Fe, NM 87508

505-466-8817 phone

fotonovela@aol.com

Everly Macario, Sc.D., M.S., Ed.M.

Public Health Communications Research Consultant 5629 S. Dorchester Avenue

Chicago, IL 60637

224.244.3965 phone

everly.macario@gmail.com

* corresponding author 